\title{
EXPERIMENTAL STUDIES OF BIRCH BARKING WASTE SHREDDING
}

\author{
Jurii Vlasov, Vladimir Katsadze, Irina Igotti, Aleksei Teppoev \\ Saint-Petersburg State Forest Technical University named after S.M. Kirov, Russia \\ gn.vlasov@yandex.ru, tlzp@mail.ru, igotti@yandex.ru, avt01@inbox.ru
}

\begin{abstract}
The study aims to obtain regression equations relating to the parameters of the knife shredder, mechanical properties of birch debarking waste, fractional composition of shredded waste and energy consumption of the shredding process. The results base on active controlled experiment, implemented to the second-order Box-Benken plan with 6 experiments in the centre of the plan. Pilot plant uses Erdwich M600 / 1400 industrial waste shredder. The experimental material is obtained after debarking birch assortments on a rotary debarking machine. The target functions include: average size of the waste after shredding and specific energy consumption. The controllable factors include: moisture content of the raw material, average particle size of the waste before shredding, angle of sharpening of the shredder knives, frequency of rotation of the shredder working body, diameter of the shredder sieve. The study compiles second-order regression equations that relate the average particle size after shredding, shredding ratio, specific energy consumption, average fraction of the waste before shredding, angle of sharpening of the knives, rotation frequency and the diameter of the sieve holes. Models are adequate by Fisher criterion. The study of the obtained equations shows that the minimum energy consumption is achieved when the angle of sharpenin $\mathrm{g}$ of the knives is $30^{\circ}$ and the rotational speed of the working body is $32 \mathrm{rpm}$. At optimal parameters of the process, shredding 10-15 times, the energy consumption for shredding the waste of birch debarking averages 1.5-2.7 MJ per kilogram of raw material, depending on its moisture content. Promising areas for further research are in the field of studying the energy consumption of shredding debarking waste of coniferous species of wood - pine and spruce.
\end{abstract}

Keywords: birch debarking waste, shredding, knife body, energy consumption.

\section{Introduction}

Timber industry enterprises produce large volumes of debarking waste. The industry faces the problem of the waste disposal [1-2]. Papers [3-7] show that debarking waste can be used as a material for briquetted biofuel production, but it is necessary to shred it to fraction of approximately $5 \mathrm{~mm}$ [813]. Papers [14-17] provide results of experimental studies of the shredding processes of pine and spruce debarking waste, but they do not take into account the factors related to the operating parameters of the shredder-machine, which limits practical application of the results. Experimental factors include only the moisture content of the raw material and the shredding ratio [14-17]. Shredding of debarking waste of hardwood, as far as we know, is practically not investigated.

The aim of the work is to obtain regression equations relating to the parameters of the knife shredder and physical properties of birch debarking waste with fractional composition of the shredding product, as well as with the energy consumption of the process. The experiments should consider the moisture content of the raw material, average size of the waste before shredding, angle of sharpening of the working member, frequency of rotation of the working member, diameter of the shredder sieve as controlled factors.

\section{Materials and methods}

The research methods include experiment planning, factorial experiment design, methods of statistical processing of experimental data.

The experimental plan of the study bases on Erdwich M600 / 1-400 industrial waste shredder, a general view of the plant is shown in Figure 1, a photo of the shredder's working member is shown in Figure 2. The plant was previously used for research [14-17], its detailed technical description is given in [14].

Target functions are the average particle size of the waste after shredding, shredding ratio and the specific energy consumption. Controllable factors include the moisture content of the raw material, average size of the waste before shredding, angle of sharpening of the working member, frequency of rotation of the working member, diameter of the shredder sieve. 


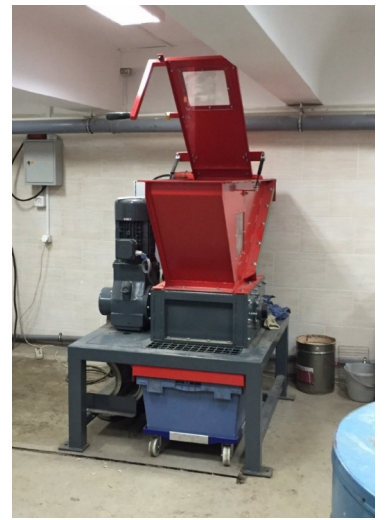

Fig. 1. General view of experimental plant

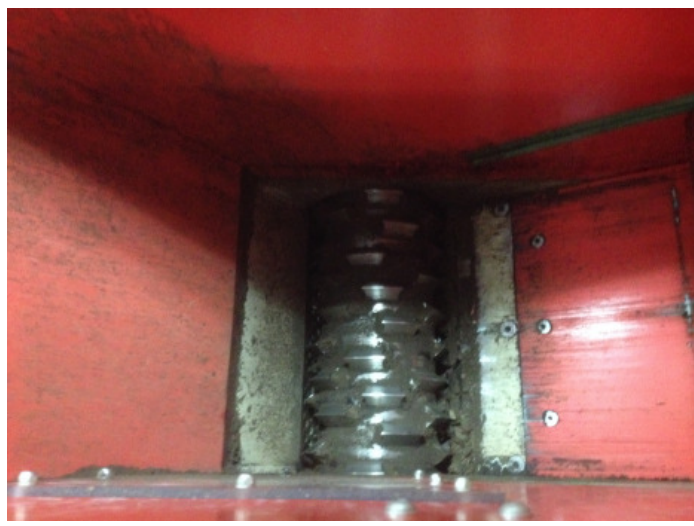

Fig. 2. Working member of experimental plant

Table 1 presents spectrum of the factor variation.

Table 1

Spectrum of variation of controlled experimental factors

\begin{tabular}{|c|c|c|c|c|}
\hline \multirow{2}{*}{$\begin{array}{c}\text { Experimental } \\
\text { factor }\end{array}$} & \multicolumn{3}{|c|}{ Value at level } & Interval \\
\cline { 2 - 5 } & $\mathbf{- 1}$ & $\mathbf{0}$ & $\mathbf{+ 1}$ & 30 \\
\hline $\begin{array}{c}\text { Moisture content of } \\
\text { the raw material, \% }\end{array}$ & 10 & 40 & 70 & 20 \\
\hline $\begin{array}{c}\text { Average size of the } \\
\text { waste before } \\
\text { shredding, mm }\end{array}$ & 30 & 50 & 70 & 15 \\
\hline $\begin{array}{c}\text { Angle of sharpening } \\
\text { of the working } \\
\text { member, }\end{array}$ & 30 & 35 & 50 & 15 \\
\hline $\begin{array}{c}\text { Frequency of } \\
\text { rotation of the } \\
\text { working member, } \\
\text { rpm }\end{array}$ & 20 & 20 & 30 & 10 \\
\hline $\begin{array}{c}\text { Diameter of the } \\
\text { shredder sieve, mm }\end{array}$ & 10 & 45 & 60 & \\
\hline
\end{tabular}

The experimental material was obtained after debarking birch assortments on a rotary debarking machine.

Specific energy consumption of shredding was determined as the ratio of the work of shredding a sample of experimental material to its mass [13-16] of $5 \mathrm{~kg}$. The shredding work was recorded using an electronic sensor built into the control panel of the shredder [13-16]. Shredding ratio is the ratio of the average size of the waste before and after shredding [13-16].

The experiment was with the second-order Box-Benkin plan with 6 experiments in the centre of the plan; the total number of experiments was 46.

\section{Results and discussion}

Processing the experimental data led to the following regression model for the average fraction of the waste after shredding:

$$
\begin{aligned}
& f=272200-3463 D-17800 \alpha+10310 n+18210 d- \\
& -61 D \alpha-131.6 \alpha n-368 \alpha d+164 n d+228 \alpha^{2}-65.76 n^{2}
\end{aligned}
$$

where $f$-average particle size of the waste after shredding, $\mathrm{mm}$;

$D$ - average size of the waste before shredding, mm;

$\alpha$ - angle of sharpening of the working member, ${ }^{\circ}$; 
$n-$ frequency of rotation of the working member, rpm;

$d$ - diameter of the shredder sieve, $\mathrm{mm}$.

Regression model for the shredding ratio is as follows:

$$
\begin{aligned}
& i=3778 D+6075 \alpha-6234 n-8175 d-32.24 D n-72.53 D d- \\
& -42.12 \alpha n-134.1 \alpha d+150.2 n d+71.35 n^{2}+216.4 d^{2}
\end{aligned}
$$

where $i$-shredding ratio.

Regression model for specific energy consumption of shredding birch debarking waste is the following:

$$
\begin{aligned}
& Q=57160-2363 n-1349 d-4.081 W \alpha+5.716 D \alpha+ \\
& 1.201 W^{2}+6.856 \alpha^{2}+30.08 n^{2}+18.08 d^{2}
\end{aligned}
$$

where $W$ - moisture content of the raw material, $\%$.

In addition, the experimental data allow to establish two more regression models for the specific energy consumption:

$$
\begin{aligned}
& Q=291 D+2627 \alpha-2861 n-3529 d+3920 f-1.715 W D+ \\
& +44.1 \alpha d-84.82 \alpha f-24.87 n f+42.11 d f-20.93 \alpha^{2}+36.8 n^{2}-25.49 f^{2} \\
& Q=-611.2 n+5055 i-16.56 W i-27.57 n i+4.155 \alpha^{2}+11.54 n^{2}-114.4 i^{2}
\end{aligned}
$$

Table 2 presents the calculated data that allow verifying the adequacy of the regression models.

Verifying adequacy of the regression models (1) - (3)

\begin{tabular}{|c|c|c|c|c|c|}
\hline \multirow{2}{*}{ Statistics } & \multicolumn{5}{|c|}{ Model } \\
\cline { 2 - 6 } & Eq. (1) & Eq. (2) & Eq. (3) & Eq. (4) & Eq. (5) \\
\hline$F$-test & 0.9097 & 1.3857 & 0.6572 & 0.4846 & 1.0969 \\
\hline$F$ & 1.4873 & 1.4873 & 1.4758 & 1.5067 & 1.4653 \\
\hline$R^{2}$ & 0.9743 & 0.9592 & 0.9738 & 0.9833 & 0.954 \\
\hline
\end{tabular}

In all cases the calculated value of the Fisher criterion is less than the critical $F$-value, thus, the hypotheses about adequacy of regression equations (1) to (5) are accepted with a significance level $\alpha=0.05$.

An example of the calculation of the specific energy consumption with the optimal shredder parameters is presented in Figure 3.

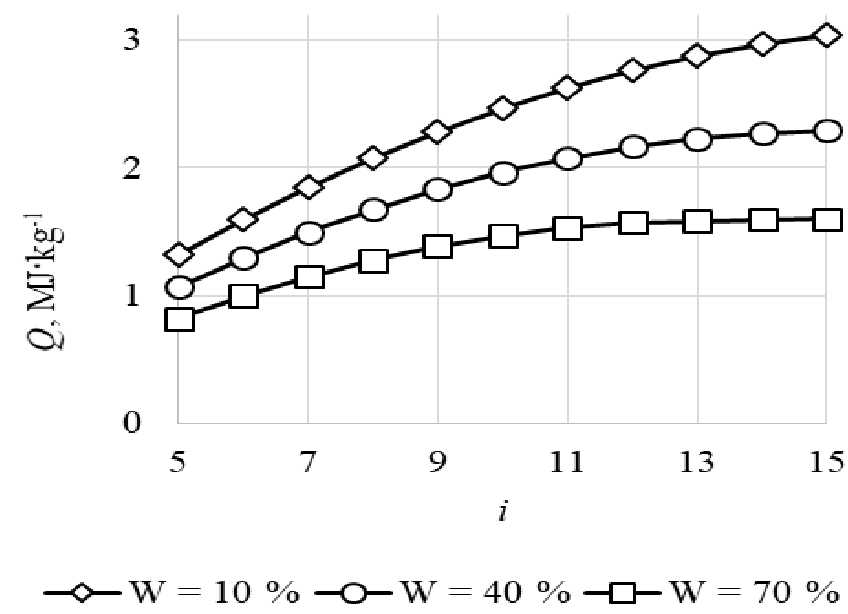

Fig. 3. Example of calculation of specific energy consumption of shredding at optimal shredder parameters 


\section{Conclusions}

1. Equations (1) to (3) allow us to calculate the average fraction of shredded birch debarking waste, the ratio of shredding and specific energy consumption, taking into account the moisture content and particle size before shredding, as well as the parameters of the shredder (angle of sharpening of knives and frequency of rotation of the machine working member, diameter of openings in the sieve).

2. Using equations (4), (5), calculation of the specific energy content of shredding is carried out, depending on the desired shredding ratio and average fraction of the waste, regarding the waste and machine parameters. Study of equations (4), (5) shows that the minimum energy consumption is achieved, when the angle of sharpening of the knives is $30^{\circ}$ and the rotational speed of the working member is $32 \mathrm{rpm}$.

3. The results of the experiments and calculations using the obtained regression dependencies show that the factors related to the knife shredder have a statistically significant effect on the energy intensity of the shredding process. At optimal parameters of the plant, shredding ration 10 to 15 times requires 1.5-2.7 MJ of energy per kilogram of raw material. Wet waste is shredded relatively easily. In the future we are planning experiments to study the energy intensity of shredding of debarking waste of coniferous species of wood - pine and spruce.

\section{References}

[1] Grigorev I., Khitrov E., Kalistratov A., Bozhbov V., Ivanov V. New approach for forest production stocktaking based on energy cost // International Multidisciplinary Scientific GeoConference Surveying Geology and Mining Ecology Management, SGEM 14, 2014. pp. 407-414.

[2] Grigorev I., Nikiforova A., Khitrov E., Ivanov V., Gasparian G. Softwood harvesting and processing problem in Russian Federation. International Multidisciplinary Scientific GeoConference Surveying Geology and Mining Ecology Management, SGEM 14. 2014. pp. 443-446.

[3] Lindner M., Sohngen B., Joyce L., Price D., Bernier P., Karjalainen T. Integrated forestry assessments for climate change impacts. Forestry Ecology and Management, №162, 2002. pp. 117-136.

[4] Rhen C., Ohman M., Gref R., Wasterlund I. Effect of raw material composition in woody biomass pellets on combustion characteristics.: Biomass and Bioenergy, 2007, pp. 66-72.

[5] Sikkema K., Steiner M., Junginger M., Hiegl W., Hansen M., Faaij A. The European wood pellet markets: current status and prospects for 2020. Biofuels, Bioproducts and Biorefining, №5, 2013. pp. $250-278$.

[6] Arun K. Tripathi, P.V.R. Iyer and Tara Chandra Kandpal. Techno -economic evaluation of biomass briquetting in India. Biomass and bioenergy, volume 14, issue 5-6, 1998. pp. 479-488.

[7] Takeshita T. A strategy for introducing modern bioenergy into developing Asia to avoid dangerous climate change. Applied Energy, №86, 2009. pp. 222-232.

[8] Fuentealba C., Salazar Montory J., Vega J., Norambuena-Contreras J. New Biobased composite material using bark fibres Euca-lyptus, 2016.

[9] Rabier F., Temmerman M., Bohm T., Hartmann H., Daugbjerg P., Rathbauer, J. et al. Particle density determination of pellets and briquettes. Biomass and Bioenergy, №30, 2006. pp. 954-963.

[10] Samuelsson R., Thyrel M., Sjöström M., Lestander T. Effect of biomaterial characteristics on pelletizing properties and biofuel pellet quality. Fuel Processing Technology, №90, 2009. pp. 1129-1134.

[11] Stolarski M., Szczukowski S., Tworkowski J., Krzyzaniak M., Gulczynski P., Mleczek M. Comparison of quality and production cost of briquettes made from agricultural and forest origin biomass. Renewable Energy, №57, 2013. pp. 20-26.

[12]Куницкая О.А., Хитров Е.Г., Ильюшенко Д.А. Уплотнение древесных материалов под действием ударной нагрузки (Compaction of wood materials under the impact action). Научное обозрение. 2012. № 4. С. 121-127. (In Russian). 
[13]Коршак А.В., Бирман А.Р., Онегин В.И., Хитров Е.Г. Брикетирование опилок на прессах ударного типа (Briquetting of sawdust with impact presses). Известия Санкт-Петербургской лесотехнической академии. 2011. № 197. С. 175-181. (In Russian).

[14]Бастриков Д.В. Повышение энергоэффективности измельчения отходов окорки на оборудовании с ножевым рабочим органом (Improving the energy efficiency of grinding debarking waste on equipment with a knife working body). Дисс. канд. техн. наук. ВГЛТУ, 2018. 118 C. (In Russian).

[15]Бастриков Д.В., Власов Ю.Н., Ильюшенко Д.А., Кучер С.В. Экспериментальные исследования энергоемкости дробления отходов окорки сосны (Experimental studies of the energy intensity of crushing pine debarking waste). Известия Санкт-Петербургской лесотехнической академии. - 2017. - № 219. - С. 120-127. (In Russian).

[16]Бастриков Д.В., Власов Ю.Н., Кучер С.В. Исследование энергоемкости измельчения отходов окорки установкой с ножевым рабочим органом (The study of the energy intensity of grinding debarking waste installation with a knife working body). Лесотехнический журнал. 2018. - T. 8. № 1. - C. 120-128. (In Russian).

[17]Бастриков Д.В., Власов Ю.Н., Кучер С.В., Куницкая Д.Е. Экспериментальные исследования энергоемкости дробления отходов окорки ели (Experimental studies of the energy intensity of crushing wastes from spruce debarking). Известия Санкт-Петербургской лесотехнической академии. - 2016. - № 217. - C. 81-90. (In Russian). 